\title{
Implikasi Keberadaan Hutan Negara terhadap Perkembangan Desa di Kecamatan Segah Kabupaten Berau Provinsi Kalimantan Timur
}

\author{
The Implication of State Forest Existence on Rural Development \\ in Segah District Berau Regency East Kalimantan Province
}

Sitti Hadijah ${ }^{1}$, Ernan Rustiadi ${ }^{1}$ and Endriatmo Soetarto ${ }^{1}$

Diterima: 11 Juli 2019

Diterima: 1 April 2021

\begin{abstract}
Abstrak: Keberadaan hutan negara diharapkan mampu memberikan manfaat sebesarbesarnya bagi kemakmuran rakyat. Tujuan penelitian ini adalah mengidentifikasi pengaruh kawasan hutan dalam perkembangan desa dan masyarakatnya dari aspek infrastruktur dan pengeluaran rumah tangga di Kecamatan Segah Kabupaten Berau Provinsi Kalimantan Timur. Metode yang digunakan analisis deskriptif dan regresi linier berganda. Hasil penelitian menunjukkan bahwa aktivitas pemanfaatan di kawasan hutan tidak nyata memengaruhi pengeluaran rumah tangga, hanya aktivitas masuk hutan yang secara nyata memengaruhi pengeluaran ke arah negatif. Artinya fungsi kawasan hutan belum mampu memberikan manfaat sebesar-besarnya bagi kemakmuran rakyat. Variabel yang secara positif memengaruhi pengeluaran rumah tangga adalah pendidikan dan luas lahan kelola. Jenis kepemilikan (milik/sewa) tidak nyata memengaruhi pengeluaran. Dengan asumsi bahwa pengeluaran mencerminkan pendapatan, ketika terjadi peningkatan pendidikan dan luas lahan kelola, terlepas dari hak atas sumberdaya (lahan) tersebut, maka akan terjadi peningkatan pendapatan.
\end{abstract}

\section{Kata kunci: hutan negara, penguasaan lahan, perkembangan desa}

\begin{abstract}
The existence of state forests is expected to provide maximum benefits for the people's prosperity. The purpose of this study was to identify the influence of forest areas in the development of villages and their communities in terms of infrastructure and household expenditure in the District of Segah, Berau, East Kalimantan Province. The method used were descriptive analysis and multiple linear regression. The results showed that the utilization activity in the forest area did not significantly affect household expenditure, only the activity of entering the forest significantly affected expenditure in a negative direction. This means that the function of the forest area has not been able to provide maximum benefits for the prosperity of the people. Variables that positively affect household expenditure were education and land area managed. The type of ownership (ownership/lease) did not significantly affect spending. Assuming that expenditure reflects income, when there was an increase in education and the area of land managed, regardless of the rights to the resource (land), there will be an increase in income.
\end{abstract}

Keywords: land tenure, rural development, state forest

\footnotetext{
${ }^{1}$ Institut Pertanian Bogor 


\section{PENDAHULUAN}

Kehutanan erat kaitannya dengan hutan, hasil hutan, dan kawasan hutan. Kehutanan tidak hanya tentang sumberdaya alam (hutan dan hasil hutan) yang terkandung didalamnya melainkan juga ruang (kawasan hutan) tempat berlangsungnya interaksi sosial, budaya, dan ekonomi. Safitri (2013) mendefinisikan hutan sebagai lanskap sosio-ekologis yang mempunyai dimensi sosial, hukum, dan aspek administratif yang memengaruhi keberadaan dan penggunaannya. Kompleksitas dari kehutanan berimplikasi pada kekeliruan yang kerap kali terjadi, misalnya antara hutan dengan kawasan hutan seringkali dianggap suatu hal yang serupa. Kekeliruan ini diindikasikan dapat memengaruhi penguasaan sumberdaya (hutan) atau dengan kata lain hak yang melekat pada sumberdaya (hutan) tersebut.

Kawasan hutan adalah wilayah tertentu yang ditunjuk dan atau ditetapkan oleh Pemerintah untuk dipertahankan keberadaannya sebagai hutan tetap (UU 411999 Pasal 1). Hal ini menunjukkan dua hal, pertama kawasan hutan adalah wilayah yang ditetapkan melalui sebuah proses penunjukan hingga penetapan oleh Pemerintah dan kedua kawasan hutan dikuasai oleh Negara. Data Statistik Lingkungan Hidup dan Kehutanan (KLHK 2017) menyebutkan bahwa luas Kawasan Hutan di Indonesia mencapai 120.4 juta ha, sementara untuk luas APL (Areal Penggunaan Lain) mencapai 67.4 juta ha. Jika dihitung persentasenya terhadap total luas daratan Indonesia maka luas kawasan hutan adalah sebesar $64 \%$ atau $2 / 3$ dari total luas daratan Indonesia. Hal ini menunjukkan bahwa daratan Indonesia sebagian besar menjadi bagian dari kawasan hutan.

Penguasaan dan pengurusan hutan oleh Negara mulai dijalankan sejak pemerintahan kolonial Belanda (Peluso dan Vandergeest 2001; Vandergeest dan Peluso 2006; Djajapertjunda dan Djamhuri 2013) bahkan setelah masa kolonial berakhir, struktur dan ideologinya masih memengaruhi praktik kehutanan Indonesia (Peluso 1991; Vandergeest dan Peluso 2006). Penguasaan hutan oleh Negara memberikan wewenang kepada Pemerintah salah satunya untuk mengatur dan mengurus segala sesuatu yang berkaitan dengan hutan, hasil hutan, dan kawasan hutan (UU 411999 Pasal 4). Sehingga, berbagai bentuk pemanfaatan dan penggunaan hutan, hasil hutan, dan kawasan hutan berada dalam domain atau ranah Pemerintah dan hal ini diatur dalam PP No. 6 Tahun 2007 jo. PP No. 3 Tahun 2008.

Pemerintah menyiapkan skema pemanfaatan hutan negara oleh masyarakat melalui skema perhutanan sosial. Pada skema ini, pemerintah menyiapkan areal seluas 12.7 juta ha dengan target desa berjumlah 6601 desa. Luas kawasan hutan yang disiapkan ini belum sebanding dengan jumlah desa yang berada di sekitar atau beririsan dengan kawasan hutan. Berdasarkan hasil survei kehutanan 2014, jumlah desa yang berada di sekitar kawasan hutan adalah sebesar 19247 desa dan di dalam kawasan hutan adalah sebesar 2037 desa. Jika dihitung persentase jumlah desa yang menjadi target perhutanan sosial, hanya $30 \%$ desa atau $1 / 3$ desa yang ditargetkan menerima manfaat dari keberadaan hutan negara. Hal ini mengindikasikan bahwa distribusi areal pemanfaatan hutan negara pada desa masih belum merata.

Desa yang berada di dalam atau di sekitar kawasan hutan disebut juga sebagai desa hutan (Djokonomo 1985 dalam Peluso 2006). Persoalan yang kerap kali ditemukan pada masyarakat desa hutan adalah kemiskinan, seperti yang terjadi pada desa hutan di Jawa (Peluso 2006) dan desa hutan di Kalimantan Timur (Dewi et al. 2005). Persoalan lainnya yaitu konflik, seperti yang terjadi di Desa Langgadai Hilir, Desa Labuhan Tangga Kecil, Desa Labuhan Tangga Besar, dan Desa Bantayan Kabupaten Bengkalis Provinsi Riau (Suharjito 2001) serta di Sumberjaya Provinsi Lampung (Verbist dan Pasya 2004). Gambaran situasi pada desa hutan tersebut diduga terjadi karena ketimpangan penguasaan atas sumberdaya. Wiradi (2009) melihat ketimpangan penguasaan lahan sebagai penyebab 
munculnya kemiskinan dan konflik. Pada konteks desa hutan, bentuk penguasaan lahan atas hutan negara salah satunya dalam bentuk pemanfaatan hutan.

Keberadaan hutan negara sebagai bagian dalam penyelenggaraan kehutanan secara tidak langsung mengandung mandat konstitusi, yaitu memberikan manfaat sebesar-besarnya kemakmuran rakyat (UU 411999 Pasal 3). Artinya, keberadaan hutan negara seharusnya memberikan pengaruh pada peningkatan kualitas hidup masyarakat khususnya yang ruang hidupnya disekitar kawasan hutan atau bahkan beririsan dengan kawasan hutan. Manfaat atas keberadaan hutan ini diduga dapat ditemukan di Kecamatan Segah Kabupaten Berau, dimana terdapat keberadaan hutan negara. Sehingga, penelitian ini bertujuan untuk menguraikan potret keberadaan hutan negara dan implikasinya pada perkembangan desa di Kecamatan Segah. Pendekatan yang digunakan adalah identifikasi struktur penguasaan lahan pada desa melalui tutupan lahan dan fungsi kawasan. Sementara itu, potret perkembangan desa diidentifikasi melalui kondisi infrastruktur desa dan pendapatan masyarakat. Secara metode penelitian ini tidak jauh berbeda dengan penelitian sebelumnya, namun yang menjadi berbeda adalah perspektif yang digunakan dalam melihat kawasan hutan.

\section{METODE}

Penelitian dilaksanakan dengan melakukan ground check pada bulan September 2018 dan mengumpulkan data sekunder pada bulan November hingga Desember 2018. Penelitian dilakukan di wilayah Kecamatan Segah Kabupaten Berau Provinsi Kalimantan Timur meliputi 13 desa.

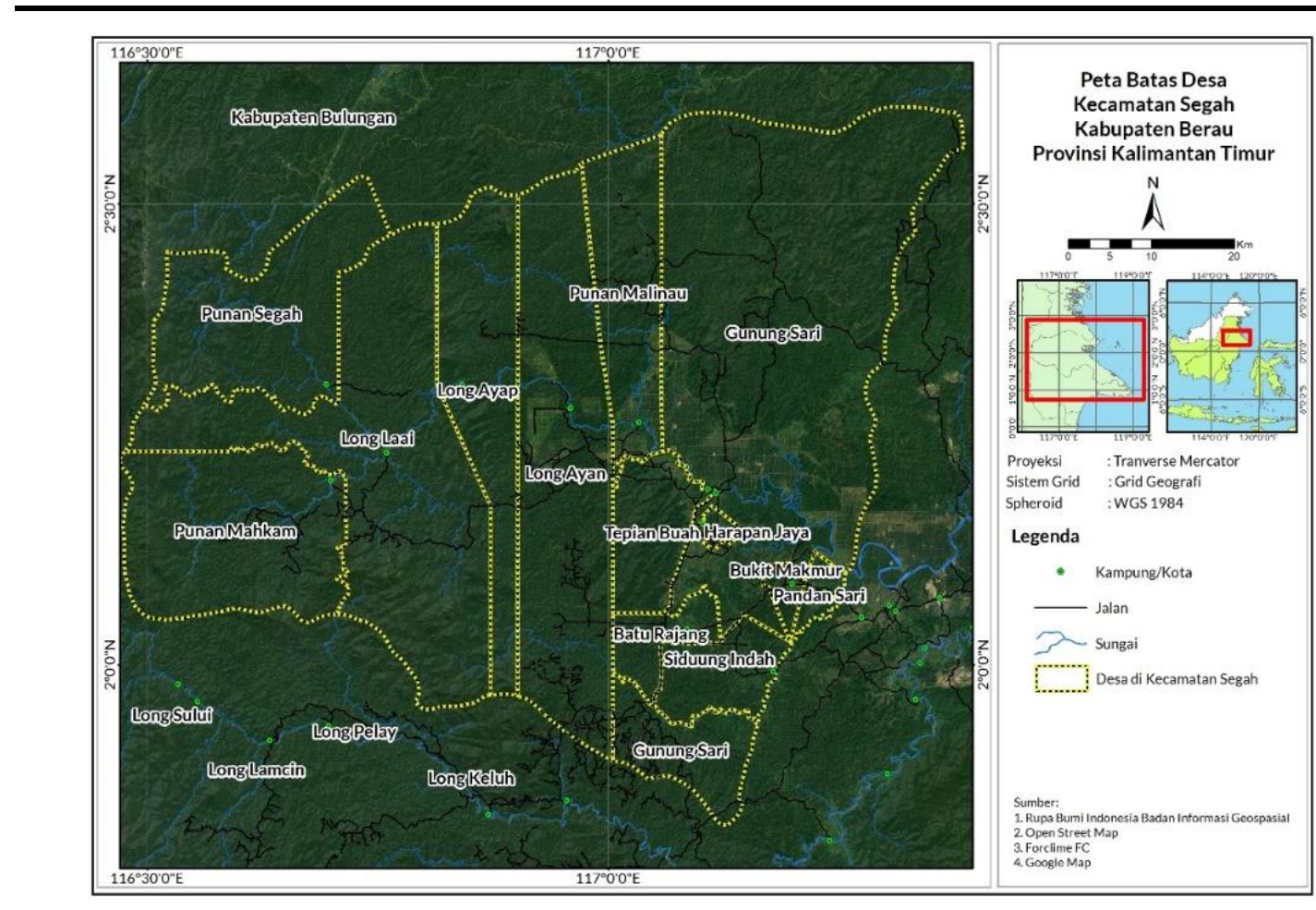

Gambar 1. Lokasi Penelitian

Penelitian ini menggunakan dua jenis data yaitu data sekunder dan data primer. Pengumpulan data sekunder dengan menggunakan data FORCLIME FC Module pada 13 desa di Kecamatan Segah. FORCLIME FC Module merupakan suatu program kerja sama 
pembangunan antara Pemerintah Indonesia dan Pemerintah Jerman pada tahun 2011. Tujuan program ini adalah melaksanakan strategi konservasi hutan dan pengelolaan hutan berkelanjutan, sehingga menghasilkan pengurangan emisi gas rumah kaca dari sektor kehutanan dan meningkatkan kehidupan masyarakat pedesaan. Lokasi berlangsungnya kegiatan FORCLIME FC Module salah satunya adalah di Kecamatan Segah Kabupaten Berau Provinsi Kalimantan Timur. Salah satu kegiatan FORCLIME FC Module adalah melakukan survei di tingkat rumah tangga pada tahun 2014. Data hasil survei yang dilakukan FORCLIME FC Module ini kemudian dijadikan sebagai salah satu sumber data sekunder dalam penelitian ini.

Pemilihan responden untuk data hasil survei FORCLIME FC Module dilakukan secara acak berdasarkan jumlah populasi setiap desa dengan ketentuan sebagai berikut: (1) untuk populasi desa berjumlah 20 rumah tangga atau kurang dilakukan dengan metode sensus (seluruh rumah tangga); (2) untuk populasi desa antara 20 hingga 60 rumah tangga, jumlah responden adalah 20 rumah tangga yang dipilih secara acak dari populasi yang ada; dan (3) untuk populasi di atas 60 rumah tangga, jumlah respondennya adalah $30 \%$ dari jumlah populasi. Berdasarkan ketentuan tersebut, total sampel survei yang dilakukan FORCLIME FC Module di 13 desa adalah sebesar 479 rumah tangga.

Data sekunder lainnya yang digunakan dalam penelitian ini yaitu data peta tutupan lahan dan peta batas kawasan yang dikeluarkan Kementerian Lingkungan Hidup dan Kehutanan (KLHK) tahun 2017, data podes tahun 2008 dan 2014, dokumen Rencana Kerja Usaha Pemanfaatan Hasil Hutan Kayu pada Hutan Alam periode Tahun 2012-2021 untuk PT. Inhutani I Unit Labanan dan periode 2013-2022 untuk PT. Sumalindo Lestari Jaya IV, dokumen Rencana Kerja Tahunan Usaha Pemanfaatan Hasil Hutan Kayu pada Hutan Alam Tahun 2018 PT. Inhutani I Unit Labanan dan PT. Sumalindo Lestari Jaya IV, serta dokumen lainnya yang relevan dengan fokus penelitian. Pengumpulan data juga dilakukan dengan mengumpulkan data primer melalui teknik wawancara mendalam (indepth interview) terhadap informan (aparat desa, masyarakat) dan melalui pengamatan lapangan (observation).

Analisis fungsi kawasan hutan dalam perkembangan desa dan masyarakatnya dilakukan dengan menggunakan metode analisis deskriptif dan analisis regresi linier berganda. Analisis deskriptif dilakukan untuk mengetahui indikasi pengaruh keberadaan kawasan hutan atas kondisi infrastruktur desa. Sementara analisis regresi linier berganda dilakukan untuk mengetahui pengaruh keberadaan kawasan hutan terhadap pendapatan masyarakat desa. Regresi linier berganda digunakan karena variabel bebas yang diidentifikasi lebih dari satu. Variabel dependen (terikat) yang digunakan adalah pengeluaran rumah tangga dan pengeluaran rumah tangga per kapita, sehingga dihasilkan 2 model regresi. Sementara variabel independen (bebas) dalam analisis ini meliputi jumlah anggota rumah tangga, lama pendidikan, luas lahan kelola, jenis kepemilikan lahan, masuk hutan, mengambil HHBK, mengambil hewan buruan, dan memanen gaharu. Alat analisis yang digunakan adalah program IBM SPSS Statistics 21. Berikut formula regresi yang digunakan dalam studi ini.

dan

$$
Y_{1}=\alpha+\beta_{1} X_{1}+\beta_{2} X_{2}+\beta_{3} X_{q}+\beta_{4} D_{1}+\beta_{5} D_{2}+\beta_{6} D_{3}+\beta_{7} D_{4}+\beta_{8} D_{5}+e
$$

$$
Y_{2}=\alpha+\beta_{1} X_{1}+\beta_{2} X_{2}+\beta_{3} X_{9}+\beta_{4} D_{1}+\beta_{5} D_{2}+\beta_{6} D_{3}+\beta_{7} D_{4}+\beta_{8} D_{5}+e
$$

Dimana:

$\mathrm{Y}_{1}$ : Pengeluaran rumah tangga (rupiah/bulan)

$\mathrm{Y}_{2}$ : Pengeluaran per kapita (rupiah/bulan)

$\mathrm{X}_{1}$ : Jumlah anggota rumah tangga (orang)

$\mathrm{X}_{2}$ : Lama pendidikan (tahun)

$\mathrm{X}_{3}$ : Luas lahan kelola $\left(\mathrm{m}^{2}\right)$ 
$\mathrm{D}_{1}$ : Jenis kepemilikan lahan $(0=$ sewa, $1=$ milik $)$

$\mathrm{D}_{2}$ : Masuk hutan $(0=$ tidak, $1=$ ya $)$

$\mathrm{D}_{3}$ : Mengambil HHBK $(0=$ tidak, $1=$ ya $)$

$\mathrm{D}_{4}$ : Mengambil hewan buruan $(0=$ tidak, $1=$ ya $)$

$\mathrm{D}_{5}:$ Memanen gaharu $(0=$ tidak, $1=\mathrm{ya})$

$\alpha$ : Konstanta

$\beta$ : Koefisien regresi

e : Error

Pada analisis ini dilakukan uji pengaruh variabel bebas terhadap variabel terikat secara parsial untuk melihat signifikansi dari masing-masing variabel bebas terhadap variabel terikat yaitu pengeluaran rumah tangga dan pengeluaran per kapita. Pengujian dilakukan dengan membandingkan nilai $p$-value (sig.) pada masing-masing variabel bebas. Model ini menggunakan derajat kesalahan sebesar $5 \%$ hingga $10 \%$ ke dalam 3 bentuk rentang nilai $p$-value, yaitu $\alpha<0.01$ artinya variabel bebas sangat signifikan memengaruhi variabel terikat, $0.01 \leq \alpha<0.05$ artinya variabel bebas signifikan memengaruhi variabel terikat, dan $0.05 \leq \alpha \leq 0.1$ artinya variabel bebas agak signifikan memengaruhi variabel terikat.

\section{HASIL DAN PEMBAHASAN}

Klasifikasi dilakukan untuk memudahkan dalam mengidentifikasi situasi yang ada pada setiap desa. Desa dengan persentase luas kawasan hutan lebih dari $60 \%$ diklasifikasikan tinggi. Hampir seluruh desa di Kecamatan Segah memiliki luas kawasan hutan lebih dari 30\% bahkan rata-rata persentase luas kawasan hutan dari seluruh desa di Kecamatan Segah mencapai lebih dari 60\%. Hanya Desa Pandan Sari dan Desa Harapan Jaya yang memiliki persentase luas kawasan hutannya kurang dari $60 \%$.

Perkembangan infrastruktur diklasifikasikan berdasarkan penentuan nilai selang kelas hierarki (Tabel 3). Hasilnya ditemukan bahwa desa-desa di Kecamatan Segah umumnya berada pada tingkat hierarki sedang dan rendah. Tingkat hierarki tinggi ditemukan pada Desa Long Ayap, Pandan Sari, dan Tepian Buah. Desa-desa ini merupakan wilayah inti karena masuk dalam kelas hierarki tinggi relatif terhadap desa-desa lainnya di Kecamatan Segah.

Tabel 1. Keberadaan Kawasan Hutan dan Perkembangan Infrastruktur Desa

\begin{tabular}{lccrc}
\hline \multirow{2}{*}{ Desa } & \multicolumn{2}{c}{ Luas kawasan hutan } & \multicolumn{2}{c}{ Rata-rata pengeluaran per kapita } \\
\cline { 2 - 5 } & Persentase (\%) & Klasifikasi & Rp/bulan & Klasifikasi \\
\hline Long Ayap & 78.60 & Tinggi & 47780.29 & Miskin \\
Siduung Indah & 96.50 & Tinggi & 97673.68 & Miskin \\
Batu Rajang & 97.41 & Tinggi & 184632.28 & Miskin \\
Punan Mahkam & 99.54 & Tinggi & 356830.07 & Miskin \\
Punan Malinau & 64.92 & Tinggi & 398020.67 & Miskin \\
Long Ayan & 78.68 & Tinggi & 412271.87 & Miskin \\
Pandan Sari & 28.88 & Rendah & 508415.59 & Miskin \\
Long Laai & 84.31 & Tinggi & 610512.71 & Tidak miskin \\
Gunung Sari & 80.08 & Tinggi & 611053.94 & Tidak miskin \\
Harapan Jaya & 0.48 & Rendah & 711815.07 & Tidak miskin \\
Bukit Makmur & 60.86 & Tinggi & 728729.21 & Tidak miskin \\
Tepian Buah & 87.16 & Tinggi & 879047.77 & Tidak miskin \\
Punan Segah & 97.59 & Tinggi & 1142879.02 & Tidak miskin \\
\hline
\end{tabular}


Tabel 12 menunjukkan bahwa desa dengan persentase luas kawasan hutannya tinggi cenderung memiliki kondisi perkembangan infrastruktur yang sedang dan rendah. Potret ini ditemukan di 9 desa dari total 13 desa yang ada di Kecamatan Segah, yaitu Desa Siduung Indah, Batu Rajang, Punan Mahkam, Long Ayan, Punan Malinau, Gunung Sari, Long Laai, Bukit Makmur, dan Punan Segah.

Perkembangan infrastruktur yang cenderung sedang dan rendah pada desa dengan persentase luas kawasan hutan tinggi terkait dengan luas lahan desa yang dapat diakses untuk membangun infrastruktur desa terbatas. Misalnya Desa Punan Mahkam, persentase luas kawasan hutannya mencapai $99.54 \%$ atau 51018 ha, artinya pemerintah desa hanya memiliki wewenang atas lahan desa sebesar $0.46 \%$ atau 235.56 ha. Dengan menggunakan asumsi bahwa setiap penduduk memiliki hak atas lahan, maka luas lahan desa dengan status APL dibagi jumlah penduduk sebesar 272 jiwa, maka penguasaan lahan adalah sebesar 0.87 ha/jiwa.

Ketika terjadi peningkatan jumlah penduduk secara tidak langsung kebutuhan lahan dalam membangun infrastruktur untuk memenuhi kebutuhan dasar masyarakat desa juga meningkat. Disamping itu, kebutuhan lainnya seperti permukiman dan lahan produksi juga akan meningkat. Hal demikian diduga akan memunculkan desakan kebutuhan lahan yang berimplikasi pada upaya masyarakat mengakses lahan di kawasan hutan.

Penguasaan efektif yang dilakukan masyarakat nampak pada aktivitas berladang dan berkebun yang ditemukan di kawasan hutan. Informasi penguasaan lahan di kawasan hutan pada unit rumah tangga di masing-masing desa tidak diperoleh, namun ditemukan bahwa terdapat penguasaan lahan oleh masyarakat di lahan tidak efektif pada areal kawasan hutan fungsi produksi yang telah dibebani izin pemanfaatan hasil hutan kayu. Total luas lahan di kawasan hutan yang dikuasai oleh masyarakat yaitu sebesar 9487 ha dari seluruh wilayah Kecamatan Segah.

Dari sisi rata-rata pengeluaran per kapita, desa dengan rata-rata pengeluaran per kapita per bulan dibawah batas abang minimum per kapita nasional desa yaitu sebesar Rp 572 586/bulan (BPS 2014), artinya desa tersebut masih dalam kondisi miskin. Lebih lanjut kondisi masyarakat desa yang masih tergolong miskin diperbandingkan dengan kondisi kawasan hutannya. Hasilnya ditemukan bahwa desa dengan klasifikasi miskin memiliki persentase luas kawasan hutan tinggi yaitu mencapai lebih dari 60\%. Desa dengan situasi demikian yaitu Desa Long Ayap, Siduung Indah, Batu Rajang, Punan Mahkam, Punan Malinau, dan Long Ayan.

Tabel 2. Persentase Luas Kawasan Hutan dan Rata-Rata Pengeluaran per Kapita

\begin{tabular}{lccrc}
\hline \multirow{2}{*}{ Desa } & \multicolumn{2}{c}{ Luas kawasan hutan } & \multicolumn{2}{c}{ Rata-rata pengeluaran per kapita } \\
\cline { 2 - 5 } & Persentase (\%) & Klasifikasi & Rp/bulan & Klasifikasi \\
\hline Long Ayap & 78.60 & Tinggi & 47780.29 & Miskin \\
Siduung Indah & 96.50 & Tinggi & 97673.68 & Miskin \\
Batu Rajang & 97.41 & Tinggi & 184632.28 & Miskin \\
Punan Mahkam & 99.54 & Tinggi & 356830.07 & Miskin \\
Punan Malinau & 64.92 & Tinggi & 398020.67 & Miskin \\
Long Ayan & 78.68 & Tinggi & 412271.87 & Miskin \\
Pandan Sari & 28.88 & Rendah & 508415.59 & Miskin \\
Long Laai & 84.31 & Tinggi & 610512.71 & Tidak miskin \\
Gunung Sari & 80.08 & Tinggi & 611053.94 & Tidak miskin \\
Harapan Jaya & 0.48 & Rendah & 711815.07 & Tidak miskin \\
Bukit Makmur & 60.86 & Tinggi & 728729.21 & Tidak miskin \\
Tepian Buah & 87.16 & Tinggi & 879047.77 & Tidak miskin \\
Punan Segah & 97.59 & Tinggi & 1142879.02 & Tidak miskin \\
\hline
\end{tabular}


Desa-desa yang masih tergolong miskin memiliki luas lahan kelola untuk aktivitas ekonomi seperti berladang dan/atau berkebun masih rendah. Persentase luas kawasan hutan yang tinggi secara langsung menunjukkan bahwa lahan desa yang berstatus APL rendah. Artinya, luas lahan yang dapat dimiliki dan/atau dikuasai oleh masyarakat untuk aktivitas ekonomi terbatas hanya di wilayah desa yang berstatus APL. Akses lahan di kawasan hutan juga dapat dilakukan, namun harus melalui skema izin tertentu yang disesuaikan dengan bentuk pemanfaatan yang ingin dilakukan.

Skema izin pemanfaatan kawasan hutan memiliki berbagai ketentuan. Hal-hal yang diatur dalam skema izin pemanfaatan adalah bentuk kegiatan pemanfaatan termasuk komoditas yang dimanfaatkan, jangka waktu dan luasan/volume pemanfaatan, subyek penerima, hingga hal-hal yang dilarang dilakukan di kawasan hutan. Berbagai ketentuan ini memengaruhi akses pemanfaatan lahan di kawasan hutan.

Lebih lanjut dilakukan analisis secara statistik untuk mengidentifikasi fungsi kawasan hutan terhadap pengeluaran rumah tangga dengan menggunakan analisis regresi linier berganda pada setiap desa di Kecamatan Segah. Ruang lingkup variabel yang digunakan dalam analisis ini difokuskan pada: (1) Kapasitas sumberdaya rumah tangga, meliputi jumlah anggota rumah tangga (RT) dan lama pendidikan; (2) Penguasaan lahan, meliputi luas lahan kelola dan jenis kepemilikan lahan; dan (3) Pemanfaatan kawasan hutan, meliputi masuk hutan, mengambil HHBK, mengambil hewan buruan, dan memanen gaharu.

Analisis regresi pada variabel dependen pengeluaran rumah tangga diperoleh nilai $R$ square atau koefisien determinasi adalah 0.165 , artinya seluruh variabel bebas memiliki kontribusi pengaruh sebesar $16.5 \%$ terhadap tingkat pengeluaran rumah tangga. Sisanya dipengaruhi oleh variabel lain diluar dari model regresi ini. Selanjutnya, uji pengaruh variabel bebas terhadap pengeluaran rumah tangga dilakukan secara parsial untuk melihat signifikansi dan arah pengaruh dari masing-masing variabel.

Tabel 3. Hasil Uji Pengaruh Variabel Bebas terhadap Pengeluaran Rumah Tangga

\begin{tabular}{|c|c|c|c|c|}
\hline Model & $\begin{array}{c}\text { Unstandardized } \\
\text { Coefficients }\end{array}$ & $\begin{array}{l}\text { Standardized } \\
\text { coefficients }\end{array}$ & Sig. & VIF \\
\hline (Constant) & 626315.273 & & 0.414 & \\
\hline Jumlah anggota RT $\left(\mathrm{X}_{1}\right)$ & 119700.486 & 0.105 & $0.016^{\star \star}$ & 1.057 \\
\hline Lama pendidikan $\left(\mathrm{X}_{2}\right)$ & 207793.852 & 0.297 & $0.000^{\star \star \star}$ & 1.123 \\
\hline Luas lahan kelola $\left(\mathrm{X}_{3}\right)$ & 9.050 & 0.164 & $0.000^{\star \star \star}$ & 1.025 \\
\hline Jenis kepemilikan lahan $\left(D_{1}\right)$ & -487316.816 & -0.030 & 0.487 & 1.033 \\
\hline Masuk hutan $\left(\mathrm{D}_{2}\right)$ & -414975.064 & -0.094 & $0.031^{\star \star}$ & 1.067 \\
\hline Mengambil HHBK $\left(\mathrm{D}_{3}\right)$ & -257287.272 & -0.061 & 0.280 & 1.782 \\
\hline Mengambil hewan buruan $\left(D_{4}\right)$ & 25205.347 & 0.006 & 0.971 & 1.764 \\
\hline Memanen gaharu $\left(D_{5}\right)$ & -146398.520 & -0.023 & 0.610 & 1.120 \\
\hline
\end{tabular}

Hasil analisis regresi (Tabel 14) menunjukkan bahwa variabel jumlah anggota rumah tangga $\left(\mathrm{X}_{1}\right)$ dan masuk hutan $\left(\mathrm{D}_{2}\right)$ memiliki nilai $p$-value pada taraf $0.01 \leq \alpha<0.05$, artinya signifikan memengaruhi pengeluaran rumah tangga. Lalu, variabel lama pendidikan $\left(\mathrm{X}_{2}\right)$ dan luas lahan kelola $\left(\mathrm{X}_{3}\right)$ memiliki nilai $p$-value pada taraf $\alpha<0.01$, artinya kedua variabel ini sangat signifikan memengaruhi pengeluaran rumah tangga. Nilai standardized coefficients juga menunjukkan bahwa variabel lama pendidikan $\left(\mathrm{X}_{2}\right)$ dan luas lahan kelola $\left(\mathrm{X}_{3}\right)$ memiliki pengaruh paling besar terhadap pengeluaran rumah tangga. Variabel lainnya pada analisis regresi ini ditemukan tidak nyata memengaruhi pengeluaran rumah tangga. Pada regresi ini tidak ditemukan multikolinearitas yang ditunjukkan dari nilai VIF $<10$ pada setiap variabel. Persamaan yang diperoleh dari hasil analisis regresi berganda dirumuskan dalam persamaan berikut: 


$$
\begin{aligned}
& Y_{1}=626315.273+119700.486 X_{1}+207793.852 X_{2}+9.050 X_{3}-487316.816 D_{1}- \\
& 414975.064 D_{2}-257287.272 D_{3}+25205.347 D_{4}-146398.520 D_{5}+e
\end{aligned}
$$

Jumlah anggota $\mathrm{RT}\left(\mathrm{X}_{1}\right)$, lama pendidikan $\left(\mathrm{X}_{2}\right)$, dan luas lahan kelola $\left(\mathrm{X}_{3}\right)$ berpengaruh positif terhadap pengeluaran RT, artinya, (1) Jika variabel lainnya nilainya tetap sementara anggota RT mengalami penambahan 1 orang maka pengeluaran RT akan mengalami peningkatan sebesar Rp 119 700.486/bulan; (2) Jika variabel lainnya nilainya tetap sementara lama pendidikan mengalami kenaikan 1 tahun maka pengeluaran RT akan mengalami peningkatan sebesar Rp 207 793.852/bulan; dan (3) Jika variabel lainnya nilainya tetap sementara luas lahan kelola meningkat $1 \mathrm{~m}^{2}$ maka pengeluaran RT akan mengalami peningkatan sebesar Rp 9.050/bulan. Sementara itu, variabel masuk hutan $\left(D_{2}\right)$ berpengaruh negatif terhadap pengeluaran RT, artinya jika variabel lainnya tetap dan dilakukan aktivitas masuk hutan maka pengeluaran RT akan mengalami penurunan sebesar Rp 414 975.064/bulan.

\section{KESIMPULAN}

Hasil analisis regresi linier berganda ditemukan bahwa aktivitas pemanfaatan di kawasan hutan tidak nyata memengaruhi pengeluaran rumah tangga dan pengeluaran per kapita, hanya aktivitas masuk hutan yang secara nyata memengaruhi pengeluaran ke arah negatif. Artinya fungsi kawasan hutan belum mampu memberikan manfaat sebesarbesarnya bagi kemakmuran rakyat. Variabel yang secara positif memengaruhi pengeluaran rumah tangga dan per kapita adalah pendidikan dan luas lahan kelola. Jenis kepemilikan lahan (milik/sewa) tidak nyata memengaruhi pengeluaran. Dengan asumsi bahwa pengeluaran mencerminkan pendapatan, ketika terjadi peningkatan pendidikan dan luas lahan kelola, terlepas dari hak atas sumberdaya (lahan) tersebut, maka akan terjadi peningkatan pendapatan. Dengan demikian, fungsi produksi atas lahan menjadi lebih penting dibandingkan status pada lahan, dalam konteks desa hutan yaitu status APL dan kawasan hutan.

\section{DAFTAR PUSTAKA}

Agung P. 2012. Pengelolaan hutan oleh masyarakat sebagai sarana untuk mendapatkan kepastian tenurial: kasus di areal hutan produksi terbatas, KPHP Unit XVI Kab. Tanjung Jabung Barat, Propinsi Jambi [Tesis]. Bogor (ID): Institut Pertanian Bogor.

Agustiono A. 2014. Kajian perubahan penggunaan lahan untuk arahan penataan pola ruang kawasan hutan produksi gedong wani Provinsi Lampung [Tesis]. Bogor (ID): IPB.

Angi EM, Wiati CB. 2017. Kajian ekonomi politik deforestasi dan degradasi hutan dan lahan di Kabupaten Paser, Kalimantan Timur. JPED 3(2):63-80.

Busck A, Hidding M, Kristenses S, Persson C, Praestholm S. 2008. Managing urban landscapes in the Netherlands, Denmark, and Sweden: comparing planning systems instruments in three different contexts. Dan J Geogr 108(2):1-16.

Djajapertjunda S, Djamhuri E. 2013. Hutan dan Kehutanan Indonesia dari Masa ke Masa. Bogor (ID): IPB Pr.

Gallent N, Andersson J, Bianconi M. 2006. Planning on the edge: England's rural-urban fringe and the spatialplanning agenda. Environ Plan b 33:457-476.

Gunawan R, Thamrin J, Suhendar E. 1998. Industrialisasi Kehutanan dan Dampaknya terhadap Masyarakat Adat: Kasus Kalimantan Timur. Bandung (ID): Yayasan AKATIGA.

Jongeneel RA, Polman NBP, Slangen LHG. 2008. Why are dutch farmers going multifunctional? Land Use Policy 25:81-94.

Karselaers E, Rogge E, Vanempten E, Lauwers L, Huylenbroeck GV. 2012. Changing land use in the countryside: stakeholders' perception of the ongoing rural planning processes in flanders. Land Use Policy 32:197-206. 
[KLHK] Kementerian Lingkungan Hidup dan Kehutanan. 2017. Statistik Lingkungan Hidup dan Kehutanan Tahun 2017. Jakarta (ID): KLHK.

Koentjaraningrat. 1972. Beberapa Pokok Antropologi Sosial. Jakarta (ID): Dian Rakyat.

Maruani T, Amit-Cohen I. 2007. Open space planning models: a review of approaches and methods. Landscape Urban Plan 81:1-13.

Panuju DR, Rustiadi E. 2013. Teknik Analisis Perencanaan Pengembangan Wilayah. Bogor (ID): IPB.

Peluso NL. 1991. The History of state forest management in colonial java. Forest and Conservation History 35(2):65-75.

Peluso NL. 1993. Coercing conservation? the politics of state resource control. Glob Environ Change 3(2):199217.

Peluso NL. 2006. Hutan Kaya, Rakyat Melarat: Penguasaan Sumber Daya dan Perlawanan di Jawa. Simatupang L, penerjemah; Fauzi N, editor. Jakarta (ID): Konphalindo. Terjemahan dari Rich Forests, Poor People: Resource Control and Resistance in Java.

Peluso NL, Vandergeest P. 2001. Genealogies of the political forest and customary rights in Indonesia, Malaysia, and Thailand. Journal Asian Stud 60:761-812.

Pemerintah Republik Indonesia. 2007. Peraturan Pemerintah Republik Indonesia Nomor 6 Tahun 2007 tentang Tata Hutan dan Penyusunan Rencana Pengelolaan Hutan serta Pemanfaatan Hutan. Jakarta (ID): Sekretariat Negara.

Pemerintah Republik Indonesia. 2008. Peraturan Pemerintah Republik Indonesia Nomor 3 Tahun 2008 tentang Perubahan atas Peraturan Pemerintah Nomor 6 Tahun 2007 tentang Tata Hutan dan Penyusunan Rencana Pengelolaan Hutan serta Pemanfaatan Hutan. Jakarta (ID): Sekretariat Negara.

Pemerintah Republik Indonesia. 1999. Undang-Undang Republik Indonesia Nomor 41 Tahun 1999 tentang Kehutanan. Jakarta (ID): Sekretariat Negara.

Popkin SL. 1979. The Rational Peasant: The Political Economy of Rural Society in Vietnam. Berkeley (US): California University Pr.

Rustiadi E, Saefulhakim S, Panuju DR. 2011. Perencanaan dan Pengembangan Wilayah. Jakarta (ID): Yayasan Pustaka Obor Indonesia.

Safitri MA. 2013. Keniscayaan Transdisiplinaritas dalam Studi Sosio-Legal terhadap Hutan, Hukum, dan Masyarakat. Di dalam: Kartodihardjo H, editor. Kembali ke Jalan Lurus: Kritik Penggunaan Ilmu dan Praktek Kehutanan Indonesia. Bogor (ID): Forci Development dan Tanah Air Beta.

Schlager E, Ostrom E. 1992. Property rights regimes and natural resources: a conceptual analysis. Land Econ 68(3): 249.

Soetarto E, Sitorus MTF, Napiri MY. 2001. Decentralization of Administration, Policy Making and Forest Management in Ketapang District, West Kalimantan. Jakarta (ID): CIFOR.

Suharjito D. 2001. Proses penyelesaian sengketa lahan hutan suatu kajian antropologi hukum: kasus sengketa lahan antara perusahaan HPH PT. Diamond Raya Timber dengan masyarakat lokal di Kabupaten Bengkalis Propinsi Riau. JMHT 7(1):1-14.

Syahyuti. 2002. Pembentukan struktur agraria pada masyarakat pinggiran hutan: studi kasus di desa Sintuwu dan Desa Berdikari, Kecamatan Palolo, Kabupaten Donggala, Sulawesi Tengah [Tesis]. Bogor (ID): Institut Pertanian Bogor.

Van Den Brink A, Van Der Valk A, Van Dijk T. 2006. Planning and the challenges of the metropolitan landscape: innovation in the Netherlands. Int Plann Stud 11:3-4.

Vandergeest P, Peluso NL. 2006. Empires of forestry: professional forestry and state power in southeast asia part 1. Environment and History 12:31-64.

Vandergeest P, Peluso NL. 2006. Empires of forestry: professional forestry and state power in southeast asia part 2. Environment and History 12:359-393.

Verbist B, Pasya G. 2004. Perspektif sejarah status kawasan hutan, konflik dan negosiasi di Sumberjaya, Lampung Barat Propinsi Lampung. Agrivita 26(1):20-28.

Wiradi G. 1978. Rural Development and Rural Institution: A Study of Institutional Changes in West Java. AgroEconomic Survey-Rural Dynamics 6.

Wiradi G. 2009. Seluk Beluk Masalah Agraria, Reforma Agraria dan Penelitian Agraria. Yogyakarta (ID): STPN Pr dan Sains.

Zasada I. 2011. Multifunctional peri-urban agriculture: a review of societal demands and the provision of goods and services by farming. Land Use Policy 28:639-648. 